\title{
Notas de Direito Comparado Privado Italo-Brasileiro (*)
}

\section{Tullio Ascareli}

SUMÁRIO: 1 - Caracteristicas gerais do direito brasileiro; 2 - Diversidades legislativas e diversidades nas orientações da prática e da doutrina; 3 - Valor da tradição juridica na América; 4 - Relação entre direito civil e comercial no Brasil; 5 - Programa; 6 - A relação entre direito e ação - A ação cambiária A ação declaratoria - A prescritibilidade da ação de nulidade; 7 - 0 aumento do valor dos imóveis e os balanços das sociedades - A prática das transmissões imobiliárias - A comunhão entre conjuges e a imigração; 8 - Disciplina legislativa e prática contratual no direito maritimo; 9 - A persistência da tradição na prática contratual, na teoria da posse - no processo. - A prática comercial e a função das sociedades anônimas - A função da cambial e as orientações doutrinárias - O desenvolvimento dos seguros.

1 - 0 direito brasileiro oferece ao jurista um particular interesse decorrente de algumas caracteristicas gerais, aliás conhecidas (1). Pertence êle, de fato, aos direitos derivados do direito romano $e$, por isso, se situa ao

(*) Este artigo reproduz substancialmente uma aula (de 1944) e constitui desenvolvimento e continuação do estudo Premissas ao estudo do direito comparado, inserto in Problemas das sociedades anônimas e direito comparado, Saraiva, São Paulo, 1945.

(1) Cf. as notas de LIEBman à edição brasileira das Istituzioni de G. Chiovenda. 
lado daqueles que igualmente derivam do velho tronco do direito romano, podendo ser incluido entre os direitos rom: nísticos.

De outro lado, porém, a historia do direito civil brasileir ' se contradistingue pela ininterrupta vigência, por mais de três séculos, das Ordenações Filipinas (2) que assim demonstraram no Brasil uma vitalidade sem paralelo na historia de qualquer outro corpo legislativo moderno.

Enquanto na Europa em geral (e mesmo na peninsula ibérica) a profunda renovação decorrente da revolução francêsa se traduzia em uma profunda renovação legislativa expressa nos códigos do séc. XIX, todos mais ou menos filhos do código napoleônico, no Brasil se passava diretamente (o que em parte se liga à propria historia politica do Brasil e às proprias circunstâncias da sua separação de Portugal e da sua independência) no direito civil, do sistema das Ordenações Filipinas ao código civil de 1916 (3).

O direito das Ordenações Filipinas, por sua vez, pode ser colocado no quadro do direito romano comum, vigente na Europa no séc. XVIII, mas dêste se distingue por um particular cunho "codicístico" das Ordenações, o qual, por seu turno se pode relacionar à historia da peninsula ibérica nos sécs. XVI e XVII e à constituição, nessa época, de um estado monárquico centralizado.

O ininterrupto vigor, por três séculos, de um corpo legislativo e a ausência, no séc. XIX, da renovação legislativa decorrente da revolução francêsa distinguem, assim,

(2) De Filipe II de Espanha (Filipe I de Portugal) de 1603.

(3) O que aproxima a historia juridica brasileira da alemã, na ?qual igualmente se passa do sistema do direito comum ao código civil de 1900 embora através as codificações particulares dos vários estados (como o código territorial prussiano) fruto do periodo iluministico. Na historia brasileira, ao contrário, a passagem, no direito civil, não é interrompida por codificações anteriores; ao passo que o é, na historia do processo civil, pois o recente código do processo nacional foi precedido de codificações processuais anteriormente vigentes nos vários Estados. 
o direito brasileiro, constituindo, quiçá, sua mais nítida característica geral (4), e dando lugar, naturalmente, a toda uma série de hábitos, conceitos, orientações e problemas, cuja origem e peculiaridade por vezes escapa ao próprio jurista brasileiro, muito embora sejam, êles, exatamente os que mais distinguem o direito brasileiro dos outros direitos de base romana. E a distinção é tanto maior quanto mais, às vezes, inconsciente, tratando-se justamente de orientações que, com o tempo, se transformaram em hábitos, parecendo, assim, naturais e inevitaveis, e, por isso mesmo, sem significação especial.

De um lado, o direito brasileiro apresenta-se dominado por um formalismo geral, pela abundância do que já foi chamado, outras vezes, de caráter ludico do direito, de outro, o jurista brasileiro, talvez mais que o europeu, tem sempre presente a diferença entre "direito" e "lei" e, menos que os outros é inclinado a deixar-se seduzir por um mero formalismo positivista, sendo levado, ao contrário, a propôr, ante a norma legal, o problema da sua conformidade com o "direito".

2 - O jurista europeu que como um viajante juridico 'desembarque no Brasil, não tardará a se orientar, dentro do sistema legislativo brasileiro, salvo, talvez, com relação a alguns capítulos do direito processual (como o dos remédios contra as decisões de primeira instância) que por sua vez se relacionam mais estreitamente com o sistema das Ordenações Filipinas. No campo do direito privado, o jurista europeu apreenderá rápidamente o sistema do código civil e rápidamente lhe encontrará as analogias estruturais com o código alemão de 1900; nem tardará a notar alguns principios básicos que estremam, o direito brasileiro,

(4) Análoga observação, tendo em vista, particularmente o processo civil, nas notas de LiEBMAN à edição brasileira (Saraiva, 1946) das Istituzioni de G. Chiovenda. 
do italiano e do francês. Assim, quanto à necessidade da tradição na transferência da propriedade e à ausência do princípio en fait de meubles possession de bonne foi vaut titre. Talvez, ainda, se de um lado verificará, especialmente com relação a.o primeiro dos dois princípios mencionados, a subsistência de problemas tradicionais que o diferente sistema franco-italiano já deixou em segundo plano (por exemplo, em matéria de constituto possessório), de outro lado notará, eventualmente com espanto, que nas consequências práticas as diferenças são talvez menores do que se poderia suspeitar. Igualmente, 0 jurista italiano conhecerá (embora já com maior dificuldade, porque o direito de familia e o sucessório estão mais intimamente ligados aos hábitos nacionais de cada qual) do regime patrimonial do matrimônio (quase que o oposto do italiano) e facilmente entenderá que, dado êste regime diverso, diversa deva ser a disciplina dos direitos sucessórios do conjuge supérstite; da constância da abertura de inventário em toda sucessão, o que, de outro lado, se harmoniza com a regra de que o herdeiro não responde em principio ultra vires hereditatis, e até da possibilidade de cláusula de inalienabilidade e incomunicabilidade que quase imediatamente lhe revelarão as características de ordem geral ha pouco mencionadas. Nem será dificil para o jurista europeu verificar a solução brasileira nas várias questões discutidas na doutrina européia - por exemplo, em materia de causa das obrigações -, mas, ao contrário, observará com interêsse o valor prático de algumas soluções propostas pela doutrina, porém não sancionadas pela lei na Europa. Igualmente imediata percepção terá o jurista europeu da conexão de alguns princípios jurídicos com as peculiaridades e as exigências de um país de imigração: jus soli contrapôsto ao jus sanguinis; lex domicilii em contraposição à lei nacional.

Mas a sensação da peculiaridade do direito brasileiro irá aumentando à medida que o viajante jurídico se voltar 
para a prática, a contratual, a processual e aquela que chamaria de doutrinária, isto é, o modo por que os problemas são, não tanto resolvidos, mas formulados na doutrina. Notará imediatamente o largo uso na prática, da doutrina francêsa e da italiana e poderá ainda observar serem exatamente estas doutrinas, mesmo (porém, não apenas) por razões linguisticas, as mais invocadas, não obstante os elementos germanistas do código civil; admirarse-à, por vezes, ao constatar que determinadas afirmações doutrinarias italianas ou francêsas, adquirem, justamente com relação às orientações gerais da doutrina brasileiras, sentido diverso, e não tardará a perceber que isso é exatamente uma consequência das peculiaridades de orientação da prática e da doutrina brasileira. Pois — e é natural e lógico que tal ocorra, e ocorre em todo país e com toda doutrina - problemas e soluções adquirem naturalmente uma extensão diversa consoante a orientação geral do leitor, e todo direito é como que dominado por aquelas premissas implícitas, como já as chamei, que mesmo antes de pesar na solução, influem na formulação dos vários problemas, na sua importância recíproca, na utilização de um ou de outro princípio, diria, mesmo, de um ou de outro instrumento jurídico para a elaboração interpretativa.

E, ao buscar as origens dessa diferença, bastante nítida na prática, embora não muito, na doutrina, o jurísta europeu não tardará a perceber que ela não repousa apenas no fato de ser o Brasil un país de imigração, na importância da sensação da existência de grandes zonas de terra livre e inexplorada e no que os norte-americanos chamam de sentido da fronteira, na intensidade e rapidez do desenvolvimento de cidades e culturas, em um forte sentido de igualitarismo social (isto é, nas características que se poderia denominar americanas); nem apenas na peculiaridade das culturas agricolas, orientadas para uma produção para exportaçâo e, às vezes, de matérias primas industriais cujo desenvolvimento, por ser conexo com as oscilações dos 
grandes mercados internacionais, dá à agricultura brasileira um caráter que um europeu consideraria "especulativo" e bem diverso do que têm a agricultura européia; nem apenas na circunstância de estar a indústria ainda em fase inicial e de desenvolvimento, com escasso mercado de capitais, com caráter predominantemente individualista; não apenas em tudo isso mas, também, em um outro fator que não direi mais importante, mas, talvez, menos evidente e mais "técnico", isto ê, na vitalidade (e como poderia ser de outro modo?) da tradição jurídica do sec. XVIII, de modo que, a miúde, se encontra a explicação de práticas e orientações doutrinárias, remontando ao direito romano comum do séc. XVIII, à permanência daqueles conceitos tornados naturais.

A vitalidade da tradição, mostra-se mais forte na prática que na doutrina, de modo que não será raro, para o viajante jurídico no Brasil, ler em um volume de doutrina uma linguagem que lhe é familiar, e encontrar-se em um mundo diverso mal desça à pratica do mesmo instituto. $\mathrm{O}$ que, aliás, não é de estranhar: quem não notou já, na própria linguagem dos contratos notariais italianos e franceses expressões e maneiras de dizer e referências que pareceriam arcáicas na linguagem comum?

Porque, na realidade, se, de um lado, a prática comercial no elaborar novos contratos ou novas cláusulas se adianta à doutrina, de outro lado esta, no seu necessário racionalisno, é bem menos tradicionalista que a prática forense e à contratual (e, no que concerne à primeira, a observação é facilmente roborada pelo exame da prática forense após a: vigência de um novo código e pela persistência, então evidente, na prática, do direito anterior) as quais, por uma natural fôrça de inércia, em parte explicada por um desejo de segurança jurídica, ficam mais ligadas às formas tradicionais. Além disso, conceitos e orientações que com o tempo se tornaram naturais, acabam por ser descuidadas pela doutrina; na prática, entretanto, imediatamente revelam sua importância. 
Todo tratadista não deixará de dedicar alguma página a uma elegante e discutida questão, embora, às vezes, de importância secundária, nem de recordar, aquí ou alí, em poucas linhas, um princípio inconcusso; não curará, todavia, de mencionar aquelas premissas gerais que, justamente porque geral e universalmente aceitas, parecem implicitas e naturais, delas podendo o proprio tratadista não estar plenamente consciente, tal como não se tem plena consciencia dos proprios hábitos e idéias mais radicadas. E é exatamente por isso que, como recordava, a asserção de um autor, aos olhos de um leitor de ambiente diverso, chega a poder adquirir um sentido diverso, porque, e perdôe-se-me a expressão, cada qual lê uma obra através dos seus proprios óculos, partindo implicitamente de certas premissas, nem sempre advertindo que elas podem ser opostas às do autor lido.

Daí poder esconder-se, às vezes, sob a aparente identidade das afirmações doutrinárias, uma diversidade real, e daí poder, a prática, revelar distinções que não se patenteiam a quem se limitar ao confronto da doutrina e legislação.

É exatamente a prática, bem mais do que a doutrina, que revela a subsistência, no Brasil, da tradição do direito comum do séc. XVIII e, mais especificadamente, do direito das Ordenações Filipinas.

Essa subsistência será notável especialmente para o jurísta italiano, pois que, em certo sentido, o direito italiano pode, por sua vez, ser caracterizado por uma acentuação dos elementos opostos.

A vitalidade da tradição do direito romano, a menor importância de elementos germânicos (pense-se, por exemplo, no sistema sucessório francês, comparado ao italiano), a historia política italiana do séc. XVII e XVIII com a consequente importância menor do fenômeno das ordenanças, o acolhimento, talvez por isso mesmo, mais amplo e integral das consequências jurídicas do movimento renovador, 
da revolução francêsa (que, sob alguns aspetos, mais se avizinham do direito romano que ao da época intermédia) contribuiram para marcar mais claramente a separação entre o direito italiano surgido das codificações do séc. XIX e o direito romano comum do séc. XVIII, especialmente o dos paises em que então atuavam (como na peninsula ibérica e consequentemente no Brasil) fatores históricos opostos aos atuantes na Itália.

Ora, é justamente dêste contraste, embora no âmbito de um quadro comum, que decorre o interêsse da comparação jurídica entre direito privado brasileiro e direito privado italiano; desde que, é obvio, a comparação seja entendida, não como uma simples justaposição de normas de lei, mas como uma real comparação de direitos, considerados na sua aplicação prática e na técnica do seu desenvolvimento interpretativo e, por isso, mesmo naquelas premissas e naquelas características, a miúde não expressas pelos respectivos autores nacionais, exatamente porque bastante naturais para serem subentendidas. Indubitavelmente, os juristas brasileiros colherão larga messe de ensinamentos, do exame aprofundado da sua história jurídica, especialmente se feito com os olhos voltados também para o direito e a prática atual que, então, melhor revelarão suas características e seus principios implicitos, seja a fim de conserválos, seja para modificá-los. Com mais nítida consciência histórica do direito próprio, torna-se mais útil e fecunda a mesma utilização da doutrina estrangeira, porque esta será melhor entendida quando identificada a diferença de problemas e orientações.

O singulạr interêsse do estudo comparado do direito brasileiro e do italiano, reside justamente no fato de que a analogia de soluções legislativas contrasta, muitas vezes, com uma diferença de prática e até de orientações doutrinárias (não obstante a utilização fundamental de uma mesma doutrina), porque é exatamente isso que permite surpreender na unidade do direito a variedade das suas orien- 
tações, dada a diversidade das condições de meio, e verĩficar como a primeira prevalece sôbre a segunda e esta, por sua vez, reage sôbre aquela.

3 - Talvez seja errôneo atribuir pouca importância à tradição no direito americano e talvez seja esta uma observação comum para quantos, pelos azares da vida, tenham tido ocasião de se fazerem viajantes jurídicos nas duas Américas: tanto nos Estados Unidos como na Argentina e no Brasil.

De um lado, talvez, convém não esquecer o valor que, mesmo em paises de formação recente, adquire a tradição; o valor que em tais casos adquire até um certo formalismo como molde que ajuda a unificar tendências diversas e a imprimir um caráter comum.

De outro lado, não convém, talvez, esquecer que, com frequência, um instituto jurídico tende a conservar a disciplina recebida por ocasião da sua recepção ou da sua primeira regulamentação em lei. Isto pode explicar tanto tradicionalismo, como modernismos do direito americano.

Ha institutos ingleses que conservam nos Estados Unidos, e especialmente em alguns estados da confederação americana, elementos tradicionais já removidos na Inglaterra; ha institutos que conservam no Brasil ou na Argentina traços tradicionais já abandonados em Portugal e em Espanha; ha, por outro lado, institutos regulados em toda a América com um modernismo desconhecido na Europa, bastando, quanto a isso, recordar o constante recurso às impressões digitais na disciplina da identificação pessoal na América.

$O$ direito inglês adotado nos Estados Unidos antes da independencia; o direito português adotado no Brasil antes da independência, quer um quer outro tende a conservar-se com formas e orientações que no curso da evolução já foram ultrapassadas na Inglaterra e em Portugal. Pode-se, aqui, apelar para a abusada e criticada (mas, ainda assim, 
não inútil) comparação com a linguagem, recordando, por exemplo, as diferênças entre o francês das províncias francesas do Canadá e o atual francês da França.

4 - Quiçá concorra, êste elemento, para explicar uma ulterior característica do direito brasileiro, que concerne à relação entre direito civil e comercial.

Enquanto, como lembrava, a codificação do direito civil é de 1916 e sucede diretamente ao sistema das ordenações filipinas, a do äireito comercial é de 1850, ligando-se, através das codificações comerciais espanhola e portuguêsa, ao tronco do código de comércio francês. Esta diferença cronológica faz com que algumas características que, na literatura internacional, se costumam indicar como típicas do "direito comercial, se encontrem no código civil. Êste adota, por exemplo, em materia de constituição em mora, o principio dies interpellat pro homine, em contraste com a diversa e formalística disposição do código de comercio que se revela, permita-se-nos a expressão, mais formalista, menos "comercialista" que o código civil. De outro lado, no código comercial brasileiro faltam princípios (em matéria de juros, de prova testemunhal, de solidariedade passiva) que se costumam indicar como típicos do direito comercial em confronto com o civil. Isso não causará espanto a quantos conceberem o direito comercial como uma categoria histórica, podendo, ao contrário, concorrer para reforçar essa concepção. A aparente civilisation du droit commercial, mo direito brasileiro (em que, de fato, na interpretação, tendem a prevalecer os principios civilisticos, e são êstes, com efeito, que maior fôrça expansiva demonstram), é, em realidade, uma confirmação da commercialisation du droit privé, porque é no código civil, mais que no comercial, que : se encontra a expressão daquela tendência que, genericamente, pode dizer-se menos formalista e, no direito comparado, é propria do direito comercial que, realmente, tem sido o seu portador. Só que a diferença de datas entre os 
dois códigos fez com que os princípios mais "modernos" e por isso mais "comercialísticos" se encontrassem no código civil, e êste, mais que o código comercial, se pudesse tornar intérprete de alguns princípios fruto das exigências do tráfico.

O exemplo talvez mereça meditação e, realmente pode concorrer para demon̄strar que a distinção entre direito civil e comercial não repousa, afinal, num contraste da "materia" regulada, mas num contraste entre princípios tradicionais e novos princípios correspondentes a novas exígencias que, embora inicialmente se afirmem em um campo limitado, tem, entretanto, em tese, um alcance geral.

5 - Para ilustrar as precedentes considerações gerais, talvez me seja permilido descer a alguns exemplos, dos quais, o primeiro concerne justamente à influência e à vitalidade da tradição do direito das ordenações filipinas na orientação doutrinária; o segundo, reflexo, mesmo sôbre questões aparentemente idênticas, do ritmo particularmente rápido de um país de imigração; o terceiro, ao reflexo, sôbre as orientações doutrinárias e jurisprudenciais, da escassez de marinha nacional.

6 - Discute a doutrina, e provávelmente sempre discutirá, o conceito de ação. Mas, qualquer que seja a sua orientação doutrinária mais detalhada, a ação se apresenta ao jurista italiano e especialmente ao do séc. XX como um meio de tutela do direito; ao jurista italiano repugna conceber o sistema juridico como ordenado em uma série de ações nominadas. $\mathrm{O}$ princípio da obrigatoriedade de todo contrato lícito e o de ter sido superada a série dos contratos nominados, bem como o da responsabilidade por todo ato ilícito culposo se harmonizam com esta concepção que abandona um formalismo, ao parecer do jurista italiano, contrastante com a própria natureza do direito moderno. Não ordena o jurista italiano, o sistema juridico segundo 
uma série de direitos a cada um dos quais corresponda uma ação determinada, mas vê, genéricamente, na ação o meio de tutela do direito, deixando aos doutos o discutir se se trata de tutela do direito objetivo ou subjetivo.

De maneira que, por serem lógicamente distintos ação e direito subjetivo substantivo, o sistema de classificação das ações se torna autônomo e independente do relativo aos direitos, passando, as ações, a ser distinguidas de acôrdo com a diferente natureza da sentença (de condenação, declaratórias, constitutivas) e não segundo a diferente natureza dos direitos (reais e pessoais).

Continua-se, naturalmente, a falar de ações reais ou pessoais, mas, então, se faz referência, em realidade, aos direitos, ou, se se quiser assim, às pretensões, antes que á ação como distinto do direito.

Vice-versa, o jurista brasileiro conserva-se, substancialmente, fiel ao sistema das ordenações filipinas e concebe o sistema juridico como ordenādo em uma série de ações cada uma das quais correspondendo a um direito: a cada direito corresponde, aos olhos do jurista brasileiro, uma ação determinada.

Daí discutir-se continuamente nos processos, a propriedade e impropriedade da ação proposta, discussão que se afiguraria a um juristá italiano, fruto de um já superado formalismo.

Dirá, o jurista brasileiro, que ao direito cambiário corresponde a ação cambiária e, sendo esta executiva (expressão que, de resto, como bem evidenciou Liebman, tem no direito brasileiro extensão bem diversa que no italiano), o direito cambiário não pode ser exercitado senão pela ação executiva. o jurísta italiano, ao contrário, observará, aliás apoiado nesse caso sobre a expressa letra da lei, que o direito cambiário tanto se pode fazer valer com uma ação de condenação como com uma ação executiva, e tanto no processo de cognıçào quanto no de execução, permanecendo inalterada a disciplina substancial do direito cambiário (e, 
por isso mesmo, a disciplina da oponibilidade das exceções) embora sendo diversa, naturalmente, a disciplina processual.

Em um caso de nulidade, o jurista brasileiro parte, implicitamente, da admissibilidade, em tese, de duas ações - a de nulidade e a declaratória, e, assim, discutirá se é ou não cabível uma ação declaratória; invocará, para demonstrar a tese afirmativa, a doutrina que vê na ação um meio de tutela do direito objetivo e nega ser, a ação declaratória, mero remédio subsidiário admíssivel sómente na falta de outra ação. O jurista italiano observará, provávelmente, que tal discussão pode ser deixada de lado; que a nulidade se coaduna sempre e necessariámente, com uma ação declaratória e que a ação para obter a declaração de nulidade de um ato é sempre e necessariamente uma ação declaratória, não importando ao caso que o código preveja ou não uma "ação declaratória" porque tal é necessariamente a caracteristica da ação de nulidade.

Acrescentará, o jurista italiano, que a ação declaratória é por sua natureza imprescritível; que o ato nulo não pode ser convalidado pelo decurso do tempo; que a proteção eventualmente concedida a quem houver adquirido por fôrça de um ato nulo, decorre de ulteriores elementos (por exemplo a posse), mas não importa numa convalidação do ato. O jurista brasileiro hesitará ante esta consequência e oporá a norma do código que declara serem prescritiveis todas as ações, nela vendo um obstáculo dificilmente transponivel. E advirta-se que é idêntico o obstáculo na legislação italiana, (especialmente no código de 1.865), sendo, em verdade, presente a.os autores do século XIX, embora viesse, posteriormente, a ser superado justamente por terem sido consideradas as caracteristicas da nulidade. Pois que, acrescentará ainda o jurista italiano, a diferença entre nulidade e anulabilidade pode ser expressa justamente na afirmação de que, no primeiro caso cabe uma ação declaratória e, no segundo, uma ação constitutiva; de que no primeiro caso, não há, enquanto, no segundo, há convali- 
dação pelo decurso do tempo. O que, acrescentaria o jurista italiano sensivel às razões sociais da diferença, pode ser explicado pelo fato de, as normas que sancionam uma nulidade, visarem proteger interêsses gerais, enquanto as que sancionam uma anulabilidade tutelam a parte certa sendo, assim, lógico que, no segundo caso, o ato possa ser convalidado pela inércia dessa parte, o que, ao contrário, seria ilógico no primeiro caso.

E o jurista italiano não recorrerá a uma ordem de idéias muito diversa no exame dos casos de alienação por parte de quem não tenha a faculdade de dispôr (como nas hipóteses da venda a non domino ou por um representante que exceda os seus poderes). Observará, então, que o ato, nos seus efeitos reais, é ineficaz e nem poderá jamais ser convalidado pelo decurso do tempo. Sua ineficacia decorre, em substância, da necessidade de proteção de terceiros, isto é, do real proprietário, não sendo ela contrariada pelo fato de, o adquirente, poder ser tutelado, dado o concurso de ulteriores circunstâncias (por exemplo, a posse) que justifiquem essa tutela não obstante a ineficácia do ato. Este ao contrário, permanece relevante nas relações entre quantos dêle participarem, dando, por isso, lugar, em caso de inadimplemento, a uma responsabilidade por danos, e esta duplicidade de consequências (nas relações internas e nas do verdadeiro proprietário) levará vários autores a falar de nulidade relativa.

Provávelmente, na discussão de um caso concreto, um advogado brasileiro e um italiano invocarão argumentos por vezes análogos e citarão os mesmos autores, mas o jurista brasileiro terá sempre em mente uma série de ações determinadas, cada uma delas correspondente a um determinado direito, enquanto que o jurista italiano se conservará sempre afastado dessa concepção.

7 - $\mathrm{O}$ afluxo de imigrantes, o rápido aumento de população, a criação, por vezes repentina, de novas cidades e 
o seu aumento rapidíssimo, o sentido, próprio de toda a América, da conquista, diria da avançada para novas terras antes virgens ou inexploradas e sua sucessiva transformação em férteis culturas, a rápida urbanização de campos dado o rápido aumento das cidades, determinam na América o célere aumento de valor da terra.

Não é sem motivo que as teorias georgistas nasceram na América, da experiência americana, e na América tiveram fortuna. O exemplo, frequente nos velhos testamentos paulistas, do testador que deixa ao filho preferido o precioso brocado ou o bem lavrado móvel francês e, ao outro, a chacara e a casinhola que hoje valem uma fortuna tornando quase inverossímil a originária relação dos valores, não encontraria frequente paralelo na velha Europa.

$\mathrm{E}$ eis, assim, porque, em matéria, de um lado tão técnica e, de outro, aparentemente tão internacional, como a dos balanços sociais, se levantará na América o problema da possibilidade de novas avaliações e se regulará (como, no Brasil, no artigo 113 do decreto-lei n. 2.627, de 26 de Setembro de 1940, sôbre sociedades anônimas) de um modo geral o problema da possibilidade de aumentar o capital social dado o maior valor adquirido pelos bens sociais.

O problema tambem se apresenta na Europa, mas tem antes de tudo como ponto de partida um outro e diverso fenômeno: o da enorme desvalorização monetária e por isso, mais que sob aspecto geral, é versado, seja na lei, seja na doutrina, com relação ao fenomeno, excepcional (ao menos teoricamente), da desvalorização. Esta, por sua vez, tambem existe na America latina, mas não encobre o fenomeno, diverso, do forte aumento de valor em virtude de um fenomeno frequentissimo de renda ricardiana.

A doutrina sulamericana será, por isso, mais sensivel ao fato de ser, o aumento de valor, se examinado com prudencia, talvez, às vezes, apenas uma esperança de lucro: a européia, ao contrário, insistirá no fato de que se trata 
apenas de uma diversa expressão monetária de bens que permanecem idênticos.

O fenômeno desde logo presente à doutrina sulamericana é o da renda ricardiana; ao contrário, aquele, mais que qualquer outro, presente à doutrina européia, é da desvalorização monetária,

A tradição européia cogita da necessidade de tutelado vendedor do imóvel; protege-o com o instituto da lesão enorme. O Brasil não disciplina tal instituto e não o disciplina porque, na realidade, no rápido ritmo de desenvolvimento do país, a hipótese, por certo não única, mas, certamente, mais presente à consciência, é a do imóvel revendido com lucro, dada a tendência de aumento de valor dos imóveis que, por sua vez, torna mais rara e menos merecedora de tutela, a venda por prêço inferior ao do mercado, dada a diversa reação social em caso de dano emergente e em caso de lucro cessante.

O contínuo afluxo de imigrantes, a criação de novas cidades e a cultura de novas terras tendem a valorizar os imóveis (e a diferença é evidente, especialmente se, como têrmo de comparação na Europa, se toma a França) e reforçar a posição do vendedor; um sociólogo poderia, talvez, observar que é principalmente através o maior valor 'dos imóveis que é cobrado o que se poderia dizer de prêmio a favor de quem chegou primeiro!

Isto deve ser entendido não só no sentido de um rápido aumento geral de valor, mas, também, no de um valor comparativamente elevado dos imóveis urbanos quase que a custo do valor naturalmente baixissimo das terras incultas; a percentagem da renda familiar, que, segundo as estatisticas, se destina ao aluguel, é, na America, com frequência, sensivelmente maior que na Europa.

Daí a difusão e a importância de um mercado imobiliário, e, se bem que, com exageração, o poder-se afirmar que o mercado imobiliário constitui, pela sua intensidade e pela própria rapidez e facilidade dos traspasses, a bôlsa do 
Brasil e desempenha, com relação ao emprêgo das econômias, a função desempenhada na Itália pela bôlsa de valores que, ao contrário, é pouco desenvolvida no Brasil.

Ao que se conjuga o enorme desenvolvimento na América, da venda de terreños a prestações a longo prazo, em medida desconhecida na Europa e com a natural formação de sociedades imobiliárias que compram vastíssimas zonas, sejam urbanas, sejam rurais, para revendê-las em lotes com um financiamento a longo prazo.

Não obstante a violência das crises, a América e especialmente o Brasil - conta sempre com um aumento futuro; ante esta previsão, a assunção de dívidas é mais fácil e natural; a difundida convicção de que, não obstante oscilações embora violentas, os imóveis aumentam de valor pelo próprio desenvolvimento do país, faz da aquisição de imóveis emprêgo típico das econômias, e por isso, justamente, difunde-se a venda de terrenos a prestações.

Tal prática dá lugar, por sua vez, a peculiares formas de publicidade imobiliária, e altera a função prática do compromisso de compra e venda que encontra sua primeira razão de ser, no Brasil, exatamente na grande difusão da venda de terrenos a prestações.

De outro lado, a falta de cadastro, a imperfeição, antes do novo código civil, dos registros imobiliários, a consequente dificuldade da exata identificação dos terrenos e de suas antigas transcrições, a frequência com que determinados terrenos, cuja extensão, dado o seu escasso valor, era indicada apenas aproximadamente, passam a ter valores colossáis, de tal modo que a diferença de poucos metros passa a representar um patrimônio superior ao prêço originariamente pago por centenas de hectares, tudo isso dá à pratica das transmissões imobiliárias no Brasil um aspecto bem diverso do que ela tem na Itália; cria problemas, perigos, artificios e abusos que só raramente encontrarão paralelo na prática italiana. 
Em um país de imigração é cotidiana e comum a história do imigrante que, chegando sem meios, consegue fazer uma fortuna; sôbre a riqueza hereditária prevalece a adquirida e a adquirida com trabalho que é sempre um pouco o do grupo familiar no seu conjunto. E eis porque a jurisprudência considera os cônjuges imigrantes como constituindo uma espécie de sociedade de fato, com relação aos bens adquiridos no Brasil e, afinal, dado que o caso, mais comum é o de patrimônios feitos no Brasil, com relação ao seu patrimônio, qualquer que seja o regime de bens no casamento. A comunhão de bens chega a adquirir, assim, nas atuais condições econômicas do país, um fundamento independente e diverso das suas origens históricas que justifica, embora sôbre roupagem diversa e de um perfil diverso, seja aplicada mesmo fora do seu âmbito originário.

8 - E comum em todos os países a luta entre carregadores e armadores. Em todos os países os segundos cuidam de, por meio das cláusulas do conhecimento, restringir e até eliminar a sua responsabilidade. Em todos os países a jurisprudência tem reagido contra tais cláusulas e, nos julgados dos países latinos, especialmente antes da convenção internacional sôbre o conhecimento de carga, tem-se recorrido, em - substância, antes de mais nada, ao princíp:o da invalidade do pacto ne dolus (ou culpa lata) praestetur, e, em segundo lugar à eventual invalidade de algumas cláuaulas, segundo o próprio direito anglo-saxão em que têm origem, visando, afinal, ora excluir, sem mais, a validade de certas cláusulas, ora limitá-la consoante os principios indicados.

Quem quer que percorra com os olhos as normas de direito maritimo do código comercial brasileiro, não tardará a reconhecer a estrutura fundamental do direito marítimo latino, às vezes, porém, (por exemplo no art. 566) com distinções de valores mais moderno que o de alguns códigos europeus contemporâneos ou (por exemplo no art. 
582) com uma orientação severa quanto às cláusulas do conhecimento que derrogam a disciplina legal da responsabilidade do armador. Ao observar a prática, todavia, notará que, na disciplina contratual do fretamento e do conhecimento de transporte, não só vigoram aquelas cláusulas que bem podem chamar-se internacionais, mas vigoram independentemente dos limites que, nos países europeus, são fruto da obra da jurisprudência e da doutrina fundadas, justamente, nas normas dos respectivos direitos nacionais. Por isso, contestações da validade de cláusulas do conhecimento, que são, por exemplo, correntes na prática marítima italiana (que o eram ainda antes da convenção internacional e do novo código da navegação que, em substâncias, acolheu os princípios daquela), são raras na pratica brasileira. Nesta de fato têm acolhida e execução as cláusulas do conhecimento (com toda a enorme extensão de exclusão de responsabilidade que elas estabelecem a favor dos armadores) e - não obstante seu frequente contraste seja com os princípios basicos dos direitos latinos, seja, muitas vezes, com os do próprio direito anglo-saxão de que derivam, o qual, por seu turno, e embora com critérios diversos (como o do Harter Act-americano com a distinção entre culpas de navegação e culpas comerciais) visou resolver o conflito com um espirito de igualdade em face dos interêsses em contraste.

De modo que ao viajante jurídico pode parecer que o quadro da prática do direito privado marítimo brasileiro, seja caracterizado pelo indiscutivel domínio de uma disciplina convencional bem distante dos esquemas do código e ditada pelo predominio dos interêsses dos armadores. 0 que talvez tem relação não com a fôrça, mas com a insuficiência da marinha nacional.

A diferença torna-se talvez ainda mais profunda ao advertir a particular frequência, na navegação brasileira, dos "tramps", e a ausência de elaboração, doutrinal e jurisprudêncial, da doutrina dos agentes terrestres do arma- 
dor. O exame desta matéria tem por fim verificar quando o agente terrestre do armador pode ser considerado investido de representação e assim, o perecer ao carregador uma proteção relativamente ao armador e ao capitão que, ausentes e distantes - e é o que se dá especialmente no caso dos tramps - não poderiam ser diretamente demandados, podendo-o ser, ao contrário, uma vez reconhecido no agente terrestre o carater de representante. Negligenciando o exame da hipótese do agente-representante do armador, chega-se na prática, especialmente com relação aos tramps, a impossibilidade prática, para o carregador, de demandar o armador ou o capitão, enquanto que o agente se entrincheirará atrás da sua irresponsabilidade.

Eis como, dada a diversa reação doutrinal e jurisprudêncial a respeito de alguns problemas, o quadro legislativo acaba por ficar nitidamente contrapôsto ao quadro da prática, e a evidente analogia do direito privado marítimo brasileiro e do italiano do código de 1.882 , cede o passo a uma diferença que, entretanto, poderia ser superada com uma diversa orientação da doutrina e da jurisprudência.

9 - Ébvio serem, os casos anteriormente apontados, meros exemplos que, facilmente, se poderiam multiplicar.

Quem queira dar-se conta da persistência e da importância da tradição do direito das ordenações filipinas no hodierno direito brasileiro, notará, para continuar nas exemplificações, a distinção no código e na doutrina, entre contrato e distrato com a consequente necessidade da aplicação, ao segundo, das formas estabelecidas para o primeiro; a presença de testemunhas nos instrumentos particulares; a forma, realmente rica de elementos lúdicos, do testamento ológrafo, bastante próximo do antigo modelo romano, mas profundamente diverso do seu homônimo italiano ou francês; e extensão (de clara origem canônica) do conceito de posse, correntemente aplicado aos cargos, não só na terminologia (como, e pelas mesmas causas, se dá também na 
Itália), mas na prática, pela redação de um documento especial de tomada de posse não despido de consequências juridicas, seja para os cargos públicos, seja para os privados.

Nem será diversa a impressão se sendo-me permitido sair do âmbito da minha competência - do direito privado se passar ao processo civil. O conjunto dos remédios contra as decisões de primeira instância no processo brasileiro parecerá, ao jurista italiano, de extrema complexidade, claramente ligada às origens históricas daqueles remédios nas ordenações filipinas; talvez o jurista brasileiro exprobe ao sistema italiano uma simplicidade que acaba por deixar de lado distinções necessárias. $\mathrm{Na}$ prática processual brasileira, o jurista italiano notará uma quase atenuação do princípio do contraditório e alguns caracteres de processo "inquisitório"; ficará surprêso ao verificar que cada parte se dirige sempre e exclusivamente ao juiz que toma conhecimento dos seus pedidos ordenando, depois, a audiência da parte contrária; com espanto constatará a possibilidade de pedir ao juiz que as proferiu, a reconsideração de alguma de suas decisões. Talvez algum observador pudesse salientar que a facilidade com que foram acolhidos no Brasil os princípios da escola processualista italiana, com a consequente acentuação dos poderes do juiz relativamente aos das partes, pode, em parte, ser explicada também pela persistência de uma tradição jurídica com os caracteres acima indicados e que são evidentes na prática processual.

o pequeno desenvolvimento do mercado de capitais, o o caráter preponderantemente individualista das iniciativas comerciais e industriais que em parte se liga à estrutura econômica do país e ao gráu do seu desenvolvimento industrial, dá às sociedades anônimas (nem por isso menos difundidas) um caráter por vezes singular. Com uma frequência que, estatisticamente, equivale à maioria dos casos, a escolha da forma anônima é devida em grande parte a razões fiscais e às vantagens fiscais dos títulos ao portador; 
a sociedade é controlada por um ou poucos individuos, embora vários testas de ferro comparecerem às assembléias, estas, com frequência, não se reunem, na realidade, limitando-se os acionistas a assinar as atas anteriormente redigidas, o que, evidentemente, facilita. a presença de quorum muito elevados; as normas destinadas à proteção das minorias transformam-se, dêsse modo, por vezes, em meras exigências formais de que a prática tende, de um lado, a desvirtuar a extensão e, de outro, talvez justamente por isso, a acentuar o formalismo.

Realmente, quem comparasse a disciplina legislativa dos institutos mais típicos da moderna vida econômica - cambial, sociedades anônimas, seguros - no direito brasileiro e no italiano não tardaria a perceber suas analogias. A comparação seria mesmo, em alguns casos, em matéria de sociedades anônimas (dec. 2.627, de 26 de Setembro de 1940) favoravel ao direito brasileiro cuja disciplina, cotejada com a do codigo de 1882 ou de 1942, é mais elaborada e moderna, especialmente quanto à tutela do acionista individualmente considerado e das minorias.

Mas, o quadro será diverso se se descer a um exame mais amplo e a diversidade decorrerá ora de diferenças econômicas, ora da persistência de orientações doutrinárias, ora de resistências psicológicas.

Não obstante a maior proteção que, em comparação com a lei italiana, a brasileira assegura às minorias, os problemas a que tal proteção dá lugar, são menos estudados, em consequência, natural, da prepoderância do caráter individualista e familiar das sociedades anônimas e da falta de um mercado de capitais. A riqueza da disciplina legislativa de alguns institutos (por exemplo, o das partes beneficiárias) corresponde a raridade da sua aplicação prática (feita, com frequência, apenas como meio indireto para fins ulteriores); à riqueza da diciplina legislativa vai de encontro uma prática estatutária comparativamente mais uniforme do que na Europa, onde, a propria variedade das exigências nos vários casos, a efetiva participa- 
ção normal de muitos acionistas e a efetiva difusão das ações 'no público, suscitam problemas que a prática estatutária procura resolver no contínuo contraste de interêsses entre maioria e minoria, entre poderes dos administradores e limites dêsses poderes; entre inovações estatutárias e sua adoção ou repulsa pelas normas legislativas.

O decreto n. 2.044 de 1908 disciplinou a cambial segundo o sistema italo-germânico, com princípios fundamentais por isso mesmo não diversos dos do código de 1.882 ou da convenção de Genebra ou da lei italiana baixada para a execução desta última, e, ao contrário, diferentes dos do sistema dito francês ao qual se poderia aproximar a disciplina da cambial no código comercial brasileiro. Mas, no comércio interno do Brasil, o lugar da cambial foi tomado por outro titulo, a duplicata que deve ser emitida e aceita em toda venda comercial de mercadorias a prazo. Por isso, enquanto no comercio brasileiro de exportação e importação, a cambial desempenha aquela mesma função que tem no comércio italiano de exportação e importação, no comércio interno seu uso é limitado a operações financeiras, ao passo que a função de meio de mobilização de créditos comerciais derivados de compras e vendas é desempenhada pela duplicata. Esta constitui o princípal título brasileiro (considerada a sua difusão prática) embora pouco elaborado pela doutrina e, até, pela jurisprudência (prescindindo, naturalmente, dos processos por falta de pagamento).

Realmente, não é sempre exato que a jurisprudência, como mais vizinha da prática, possa adiantar-se à doutrina na elaboração de novos institutos: a jurisprudência só pode examinar as questões que lhe sejam propostas, e sempre será dificil que se lhe proponham questões ignoradas na doutrina; mesmo o mais hábil advogado não se aventurará facilmente em um caminho que seja privado de precedentes, ao menos doutrinários. 0 que, no fundo, para continuar neste parêntese, constitui por vezes a diferença en- 
tre o advogado e o jurista: o primeiro deve, no interêsse do cliente, buscar demonstrar que a solução que propõe é a que sempre tem sido adotada, não oferecendo, assim, nenhum caráter de novidade, mas correspondendo, ao contrário, ao anteriormente afirmado pela doutrina e pela jurisprudência; o segundo, ao invés, especialmente na Europa, procura seguir novos caminhos, levantar novos problemas, reexaminar velhas soluções, sendo esta, exatamente, uma das suas funções. Eis porque a falta de elaboração da duplicata na doutrina brasileira (não obstante a grande elaboração doutrinária da cambial) explica a falta de sua elaboração jurisprudêncial.

O viajante jurídico que dê com esse título, talvez venha a não concordar com a sua construção dogmática corrente no Brasil; não tardará, porém, a notar que na duplicata reaparece o requisito da "provisão", abandonado na cambial, com o decreto n. 2.044, e, mais, reaparece com especial intensidade e particularidade. Então poderá, talvez, notar que, sob a criação legislativa da duplicata, possa mesmo existir uma certa reação contra o sistema cambiário italo-germânico acolhido no decreto n. ${ }^{\circ}$ 2.044. E, talvez, considerada a questão sob êste aspecto, melhor perceberá o porque da diferença máxima entre a duplicata brasileira de um lado e de outro lado o análogo título português, chamado extrato de fatura, ou a tendência, aliás própria de muitos países (por exemplo, a França) de considerar lícito, em determinados casos, a emissão da cambial independentemente do consentimento do sacado, e obrigatório o aceite.

Com efeito, enquanto no Brasil a duplicata é necessária para toda compra e venda mercantil de mercadoria a prazo, em Portugal o extrato de fatura é emitido sómente quando não houver sido já préviamente sacada uma letra de câmbio. A diferença relaciona-se, indubitavelmente, com o fato que a duplicata brasileira constitui o meio de arrecadação de um imposto especial sôbre vendas mercantis, porém talvez não seja de todo estranha à configuração do 
título, uma certa reação nos confrontos do sistema cambiário do decreto de 1908 e da orientação então adotada quanto à cambial. Esta, por outro lado, à vista da existência da duplicata, constitui, antes de tudo, no comércio interno, o instrumento de operações financeiras, o que, por vezes, leva a acentuar sua abstração, considerada, então, com um absolutismo que não encontra facilmente paralelo na Itália. Assim, de um lado, a própria existência da duplicata e a velha tradição do código comercial constituem obstáculos a percepção das caracteristicas do sistema adotado no decreto de 1908 (como é evidente com relação à ação de enriquecimento, com frequência entendida na doutrina e na jurisprudência brasileira em sentido não diverso daquele em que a doutrina italiana fala de ação causal), de outro lado, a acentuação da importância da cambial como instrumento de operações financeiras, leva a acentuar a abstração dela. E, por vezes, as suas tendências, posto que opostas, acabam coincidindo nos resultados, mediante a doutrina da cambial como "prova legal" Assim, é que, em cuidado e recente estudo brasileiro sôbre as exceções cambiárias, se pode ler que, quanto à possibilidade de opor as exceções causais, há em campo três teorias: a que admite a oponibilidade das exceções ex causa inter partes e a terceiros; a que exclui a oponibilidade seja a terceiros seja inter partes; a que admite a oponibilidade inter partes, excluindo-a, porém, quanto a terceiros. O jurista italiano representa uma situação histórica agora longínqua, e cujo superamento se liga justamente a afirmação da qualidade de título de crédito na cambial; a segunda constitui uma inoportuna exageração da abstração cambiária; enquanto que a terceira constitui, não a conclusão, mas, antes, a primeira das várias doutrinas cambiárias que devem fundamentar a oponibilidade das exações causais inter partis e a sua inoponibilidade a terceiros, passando, posteriormente, a melhor identificar quem seja o "terceiro" ao qual não se possam opôr exceções (se o terceiro "ignorante" e se aquele 
que, adquirindo a cambial, não tenha agido cientemente, em prejuizo do devedor, e, neste ultimo caso, qual seja o preciso alcance do adverbio "cientemente" e assim por diante).

Por isso, ao final do seu exame, o quadro que se apresentará ao viajante jurídico, quanto à cambial, será bem diverso que se apresentava a princípio, e, talvez, mais do do que a analogia, ser-lhe-á presente a diferença entre a situação jurídica brasileira e a italiana. Esta diferença, por sua vez, não decorrerá, antes de mais nada, de diversidades na disciplina legislativa cambial nos dois países (dada a possibilidade, no Brasil, de uma letra de câmbio ao portador; ou a inexistência no Brasil, do endosso cambiário em garantia; dada às dúvidas na doutrina brasileira, sôbre a disciplina da ação do avalista contra o avalizado, e assim por diante), mas, de uma série de diversidades provenientes do concurso de outros institutos, das diferentes funções econômicas do mesmo instituto, da diversidade de orientações doutrinárias, justamente mais implicitas que explicitas, mais subtendidas que declaradas.

Não será diverso o quadro, passando-se ao terceiro dos supra mencionados institutos, isto é, o dos seguros. O escasso desenvolvimento prático do seguro de vida não deixará de impressionar o viajante jurídico, o qual, talvez, advertirá que a econômia, èm alguns países (especialmente na America do Norte) canalizada sob a forma de seguro, escolhe, ao contrário, no Brasil, o caminho da compra de uma casá própria, segundo uma orientação que a tendência de aumento do valor dos imóveis, de um lado, e a desvalorização da moeda, de outro, tornam facilmente compreensível e justificado. Ficará tambem o viajante juridico impressionado pelo escasso desenvolvimento do seguro contra a responsabilidade civil. Indagando as razões dessa escassez, não deixará de observar a raridade dos casos em que é invocada a responsabilidade do preponente por culpa do preposto, nem de notar que, ademais, dita responsabi- 
lidade seja raramente invocada, mesmo com referência à responsabilidade do proprietário do automovel por danos causados por êste - quando guiado por um chofer.

Por isso, os processos de responsabilidade civil por acidentes de automóvel, tão frequentes, cotidianos na Europa, são, ao invés, raros no Brasil. Menos frequente, em consequência, porque de menor interêsse, o seguro contra a responsabilidade civil. Retornando, mentalmente, à situação vigente na Europa antes das leis que nos últimos decênios e em quase todos os Estados, regularam a responsabilidade do proprietário do automóvel, o viajante juridico notará que a diferença, não decorre, apenas, dessa diversidade de disciplina legislativa, mas de uma concepção diversa da responsabilidade do preponente pelos atos do preposto, de que, a diferença na legislação automobilística, é afinal, apenas uma consequência. Não obstante a redação substancialmente análoga das normas dos códigos civis, a doutrina e a jurisprudência brasileira interpretaram aquela responsabilidade de modo bem mais restrito que a jurisprudência européia, permanecendo, mais do que esta última, ligado aos critérios tradicionais da culpa in eligendo e in vigilando. $\mathrm{E}$, talvez, continuando nas suas observações e passando da responsabilidade civil automobilística às considerações da jurisprudência sôbre os danos às pessoas (que, na prática, frequentemente se ligam à primeira, nos processos europeus) o viajante jurídico verificará que, no Brasil, é ainda mais do que nos outros países latinos, acentuada a resistência psicológica a admitir, que uma importância em dinheiro possa constituir a reparação de um dano a pessoas. Talvez, em matéria de ressarcimento de danos, esta resistência, caracteriza de modo geral os direitos latinos com relação aos anglo-saxões, e caracteriza, especialmente, o direito brasileiro. Aos olhos do jurista brasileiro, a idéia do ressarcimento pecuniário de um dano à pessoa, terá sempre algo por demais materialístico que o levará a avaliações comparativamente modestas. 
E, assim, o viajante juridico descobrirá justamente, sob a aparente diversidade, analogias, e, sob as analogias, diversidades, e poderá, na unidade do direito, encontrar uma variedade de orientações, relacionadas às diversas tradições nacionais e condições ambientais. $O$ interêsse do direito comparado decorre justamente dessa complexidade e, sob êste aspecto, o direito comparado privado italo-brasileiro pode apresentar interêsse especial, decorrente de uma substancial unidade sólidamente fundada no velho tronco romano, porém com notáveis diversidades, e da influência a respeito, mais do que das diferenças de legislação, das diversas orientações práticas e doutrinárias relacionadas às diversidades ambientais e econômicas, de um lado, e às da tradição histórica, de outro. 